\title{
Testing the intermediate disturbance hypothesis: response of fouling communities to various levels of emersion intensity
}

\author{
Mark Lenz*, Markus Molis, Martin Wahl \\ Leibniz-Institut für Meereswissenschaften an der Universität Kiel, Düsternbrooker Weg 20, 24105 Kiel, Germany
}

\begin{abstract}
Connell's intermediate disturbance hypothesis (IDH) postulates that diversity peaks at an intermediate level of disturbance frequency or intensity. To test the validity of this concept for the species-poor marine hard-bottom community of the Western Baltic, we chose an in situ experimental approach. Undisturbed fouling communities of 2 different successional stages, 3 and 12 mo old, were submitted to various levels of emersion intensities, defined as time spans of continuous exposure to the air $\mathrm{d}^{-1}$. Disturbance levels ranged from $0.25 \mathrm{~h}$ up to $12 \mathrm{~h}$ of daily exposure. The study on 3 mo old communities was repeated in 2 subsequent years, 1999 and 2000. Species richness, evenness and diversity (Shannon index) were recorded to measure the effect of intensity treatments on community structure. The IDH was confirmed in the first year, when diversity was found to peak at intermediate disturbances. However, for communities of both successional stages, diversity-disturbance relationships were U-shaped or not significant in the second year. This ambiguous picture basically confirms the validity of the mechanisms proposed by the IDH, but shows that their forcing can be masked by fluctuations in environmental parameters, such as climatic conditions. An extension of the model is proposed, that considers diversity enhancement under extreme conditions due to a disturbanceinduced change in community structure. Furthermore we discuss a conceptual linkage of the IDH to the multiple stable-state hypothesis. Finally, we found community stability not to be positively correlated with community age and complexity.
\end{abstract}

KEY WORDS: Intermediate disturbance hypothesis · Diversity · Disturbance · Fouling communities · Community structure $\cdot$ Mytilus edulis

Resale or republication not permitted without written consent of the publisher

\section{INTRODUCTION}

During the last 4 decades, the question as to how diversity is generated and maintained in ecological communities and the search for causes of patterns of species diversity have been hotspots in the discussion among community ecologists. Grime (1973) provided a graph that described species richness as a unimodal function of disturbance. This concept was picked up by Connell (1978), who coined the term 'intermediate disturbance hypothesis' (IDH). The IDH states that species richness is highest at intermediate frequencies or intensities of disturbance, while too intense or too frequent disturbances exclude all species but the most resistant. On the other hand, too weak or too rare disturbances are not capable of preventing the exclusion of competitively inferior species. At intermediate disturbance levels, pioneer species are able to reestablish and coexist with the dominant competitors, while the latter are suppressed in their abundances but not fully removed from the system (Grime 1973, Connell 1978, Huston 1979, Petraitis et al. 1989).

Because of its attraction to community ecologists, the IDH has been the subject of numerous studies. Mackey \& Currie (2001) reviewed 85 IDH studies published between 1985 and 1996 and references therein, and separated experimental studies from correlative studies using an appendix available from the Ecological 
Archives of the Ecological Society of America. They found that only $30 \%$ of the 85 studies comprised experimental approaches; in these manipulative studies, a unimodal curve was detected in 3 experiments and was absent in all other cases. In 3 further experimental studies, Flöder \& Sommer (1999) and Widdicombe \& Austen $(1998,1999)$ confirmed the IDH. Nevertheless, the overall picture reveals a mismatch between the unanimous acceptance of species diversity as a unimodal function of disturbance in the ecological literature and the weak existing experimental evidence for the concept. This circumstance and the significance of the model as a central paradigm in community ecology make further experimental investigations of the diversity-disturbance relationship necessary.

In this study, the impact of various intensities of emersion on 3 and 12 mo old western Baltic fouling communities was investigated; emersion intensities were defined as varying durations of continuous emersion $\mathrm{d}^{-1}$. Emersed marine organisms are confronted with a multitude of physiological strains, such as restricted photosynthetic activity or nutritional intake, temporal dehydration, osmotic stress, freezing, overheating or increased UV radiation. Although the Baltic Sea has almost no tides, emersion is aperiodically but frequently experienced by fouling assemblages in the upper subtidal of the Western Baltic. The tide-related diurnal water-level amplitude lies below $15 \mathrm{~cm}$ (Lass \& Magaard 1995), but this can be exceeded $>15$-fold by wind-driven changes in water-level (M. Lenz pers. obs.). Such conditions can last from hours to days, depending on the predominant wind conditions.

With regard to the intermediate disturbance hypothesis, the present study addressed the following questions: (1) Are dominant competitors detectable in the fouling community investigated? (2) Is the competitive exclusion principle suppressed by the applied disturbances? (3) Is there an intermediate range of emersion duration that produces maximum diversity? (4) Are older communities less susceptible to the disturbance regimes applied? (5) Are processes consistent between years?

\section{MATERIALS AND METHODS}

Study site and fouling communities. All experiments were conducted from May 1999 to December 2000 in the Kiel Fjord. The study site was located at the mouth of the Kiel Canal $\left(54^{\circ} 22^{\prime} \mathrm{N}, 10^{\circ} 09^{\prime} \mathrm{E}\right)$ in a small sheltered bay.

Fouling communities in Kiel Fjord older than 1 yr are generally dominated by the blue mussel Mytilus edulis (M. Lenz pers. obs.), this mussel being one of the dominant competitors for space in the Western Baltic. The second dominant local species is the barnacle Balanus improvisus. Other important faunal components beside the 2 main competitors are the hydroid Laomedea flexuosa, the spionid polychaete Polydora sp. and the bryozoan Membranipora membranacea. Floral components of the communities are the green alga Enteromorpha sp., the sea-lettuce-like Ulvopsis grevillei, the filamentous Chaetomorpha tortuosa and Bryopsis plumosa. The predominant red alga is Ceramium strictum. Benthic diatoms are omnipresent. The main motile benthic predators in this system are the shore crab Carcinus maenas and the starfish Asterias rubens. The most important grazers are the periwinkle Littorina littorea, the isopods Idotea spp. and the amphipods Gammarus spp. All but the 2 latter genera were excluded from the experimental units by the experimental set-up.

Settlement panels and maturation of communities. PVC-panels of $7 \times 7 \mathrm{~cm}$ served as settlement substrata for the fouling communities.

To obtain communities at various stages of succession, 150 bare panels were exposed to colonization in a water depth of 20 to $30 \mathrm{~cm}$ in May 1999. Of these, 34 were used for the first experiment (i.e. exposed to emersion treatments) 3 mo later. Communities on the remaining panels were allowed to mature for another $9 \mathrm{mo}$, and were used for the second experiment in May 2000 . Subsequently, these were replaced by bare panels on which fouling communities developed for $3 \mathrm{mo}$; these were used for the third experiment in late summer 2000 (Fig. 1).
Fig. 1. Time schedule for maturation periods and emersion experiments in the 2 study years. $A_{1}$ : study on 3 mo old fouling communities in 1999; $\mathrm{A}_{2}$ : study on 3 mo old communities in 2000; B: study on 12 mo old communities (maturation began in 1999 and experiment was conducted in 2000); $\mathrm{n}$ : number of replicates (1999 experiment was initially designed with 4 replicates, but was considered as non-replicated because of pseudo-replication of panels)

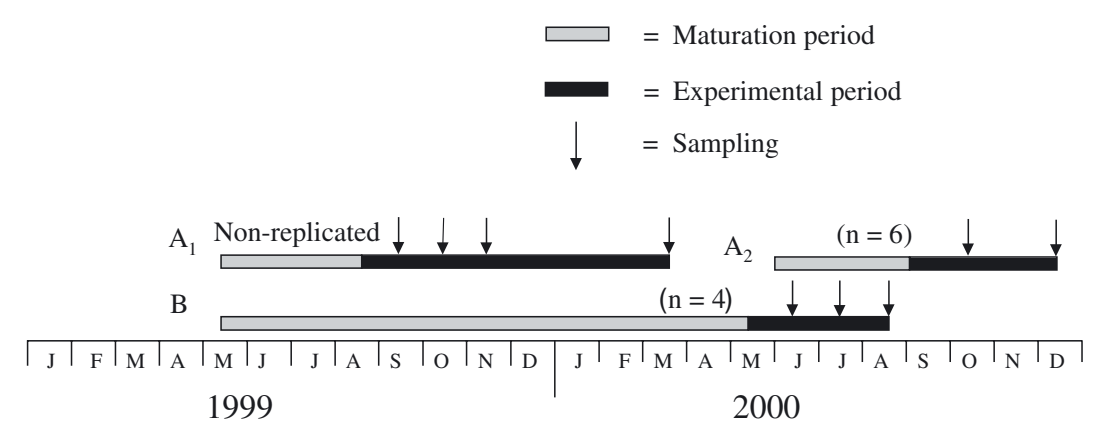

1999 
Initial values of all diversity parameters for reference (Time zero, $t_{0}$ ) were obtained from 6 or 8 randomly chosen panels at the end of the maturation period.

Experimental set-up. The experimental set-up was mounted on wooden rafts $(3 \times 10 \mathrm{~m})$. Emersion of settlement panels was realized by an automatically controlled seesaw system. Settlement panels were fixed to PVC rings (in 1999) or carrier plates (in 2000) at the end of a thin rope attached to one end of the seesaw. The panels were fixed to the rings or carrier plates by either Velcro ${ }^{\circledR}$ or cable ties.

To achieve the submersed state, the seesaws were tipped toward the water and the settlement panels were immersed in a water depth of $20 \mathrm{~cm}$, i.e. the water depth at which they had matured.

At the shorter end of the seesaws was a container that could be filled with seawater by an immersed pump. The weight of the inflowing water tipped the seesaw and lifted the settlement panels $20 \mathrm{~cm}$ above the water level. Seesaws remained in this position as long as the pumps were running, i.e. as long as the disturbance treatment was applied.

During the second experiment in 2000, procedural controls were run to test whether the process of breaking through the water surface had a mechanical impact on the communities, thus confounding the disturbance-treatment effects: the control seesaws were lifted manually out of the water and dropped back immediately, 10 times in quick succession on $5 \mathrm{~d}$ each week during the summer (May to September) and $3 \mathrm{~d}$ each week during the winter.

Experimental design. All experimental units of the 1999 study were located on 1 raft. Settlement panels were fixed to PVC rings, $31.5 \mathrm{~cm}$ in diameter; each ring carried 4 equidistant panels as replicates. We distributed 9 different emersion treatments randomly among the seesaws; 4 undisturbed panels served as controls. Statistical evaluation of the obtained data was restricted due to pseudo-replication, since replicate panels were located on 1 ring and were not spatially distributed.

A complete randomized block design was realized in 2000, whereby 42 seesaws were evenly distributed among 3 experimental blocks with each block located on a separate raft and a distance of approximately $15 \mathrm{~m}$ between blocks. Each seesaw carried 1 settlement panel that represented 1 replicate of the respective treatment. Each treatment was replicated twice within each block in the study on 3 mo old communities in 2000 $(\mathrm{n}=6) ; 4$ replicates were used in the study on 12 mo old communities. Treatments, procedural controls and undisturbed controls were allocated randomly among seesaws.

The durations of the emersion treatments applied in the 2 study years are shown in Table 1 . In both years, 4 treatment levels were identical $\left(0.25,1,2\right.$ and $\left.6 \mathrm{~h} \mathrm{~d}^{-1}\right)$, but in 2000 the disturbance gradient was extended. In 1999, the highest disturbance level was $8 \mathrm{~h} \mathrm{~d}^{-1}$, while in 2000 the most severely disturbed panels remained emerged for $12 \mathrm{~h} \mathrm{~d}^{-1}$. The temporal center of the treatments was switched from noon to midnight and vice versa at $1 \mathrm{wk}$ intervals to achieve more natural emersion regimes.

Generally, fouling assemblages consist of species with generation times encompassing several temporal magnitudes extending from days (diatoms and ciliates) to years (mussels and barnacles). When disturbing a community as a whole, it is almost impossible to choose disturbance intervals related to the generation times of all organisms as required by Pickett \& White (1985). Therefore, disturbance intervals were chosen that were feasible and within the general temporal range of natural low-water situations. For the same reason it was impossible to define all emersion events for each individual species as a disturbance (i.e. 'removal of biomass', sensu Grime 1973) or as stress (i.e. 'restriction of productivity', sensu Grime 1973), since treatments were applied to complex communities and encompassed a wide range of intensity levels. For the community as a whole, they represented more of a disturbance/stress mixture. Such restriction in methodical stringency is unavoidable in experimental field studies of natural and complex communities.

Larval supply was monitored on recruitment panels exposed every month and retrieved $4 \mathrm{wk}$ later in both study years. The course of undisturbed succession at the study site was followed on 8 panels (not included in the experiments) from May 2000 to May 2001.

For comparison of climatic conditions in the 2 study years, meteorological data were acquired from the Leibniz-Institut für Meereswissenschaften, Kiel.

Table 1. Intensity treatments applied to fouling communities in the 2 study years. Daily temporal center of emersion treatments (12:00 or 24:00 h) was changed weekly. +: applied; -: not applied

\begin{tabular}{|lcc|}
\hline Emersion $\left(\mathrm{h} \mathrm{d}^{-1}\right)$ & 1999 & 2000 \\
\hline 0.25 & + & + \\
0.5 & + & - \\
0.75 & + & - \\
1 & + & + \\
1.5 & + & - \\
2 & + & + \\
4 & + & + \\
6 & + & - \\
8 & + & + \\
12 & - & \\
\hline
\end{tabular}




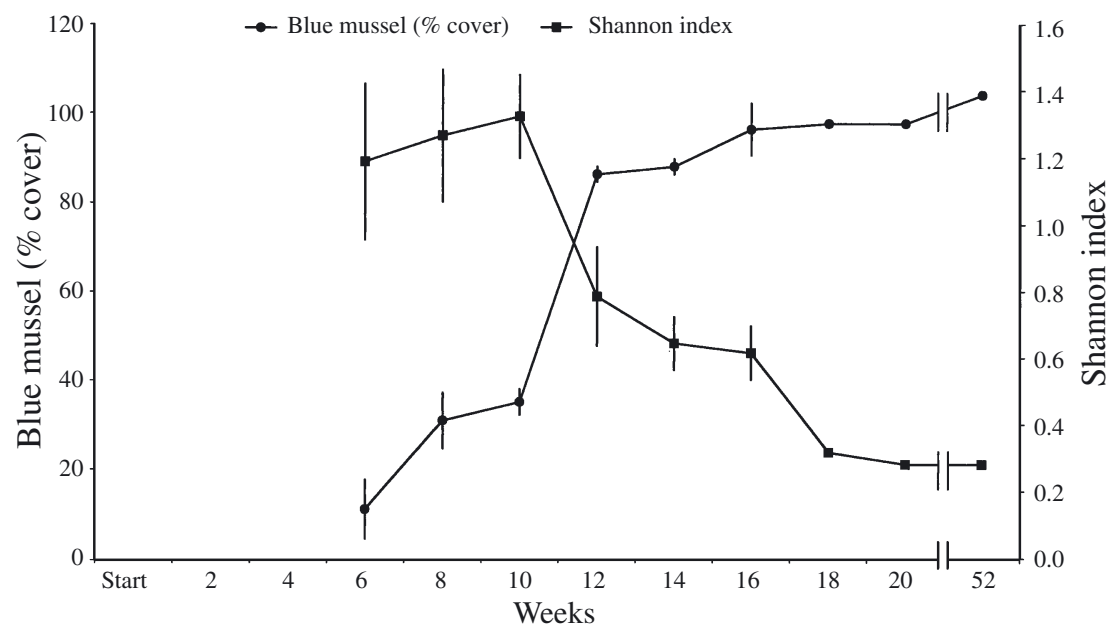

Fig. 2. Shannon index and percent cover of blue mussels (mean $\pm \mathrm{SE}$ ) sampled every 2 wk from May to October 2000 and again in May 2001 gression. Linear regression analysis (lr) was used to test for significant interactions between the disturbance gradient and response variables other than the diversity parameters. Correlations were analysed by Spearman's rank correlation (src).

Because of the non-replicated experimental design of the 1999 study, only mean values, calculated from the 4 treatment panels, were used to plot these data and no ANOSIM and SIMPER analyses were done. A 2-tailed Student's t-test and a nonparametric KruskalWallis ANOVA were used for analysis of meteorological data.
Sampling procedure and statistics. Settlement panels were sampled monthly, except during the last experiment in fall 2000 when sampling took place after 6 and 14 wk (Fig. 1). The sampling procedure was non-destructive: panels were retrieved from the carrier plates, placed in water-filled containers, examined in a nearby field laboratory, and then returned to their respective plates. Within 15 min (per panel), percent cover of all settlers was estimated (5\% resolution) and blue mussels were counted and divided into size classes using 3 fields of vision (covering $40 \%$ of the whole panel surface) under a Wild binocular at $12 \times$ magnification. To avoid 'edge effects', the outer $1 \mathrm{~cm}$ of the panels was not included. Total percent cover exceeded $100 \%$ in the case of multi-strata growth.

Similarities between communities were assessed on untransformed data by multivariate 1-way analysis of similarity (ANOSIM) based on the Bray-Curtis similarity index (Clarke 1993). Subsequent SIMPER (similarity percentage) analyses (Clarke 1993) were used to quantify the contribution of each species to dissimilarities between communities. The PRIMER software package from the Plymouth Marine Laboratory (UK) was used for both analytical methods. For the ANOSIM and the SIMPER analysis, benthic diatoms were treated as 1 taxon. They were excluded from the calculations of diversity parameters. Differences in percentage cover of blue mussels between treatments were tested for significance by ANOVA. The IDH prediction of a unimodal response curve was tested by a 2nd-degree polynomial regression (pr), while the fit of the data to the proposed sinusoidal model was tested by a 3rd-degree polynomial re-

\section{RESULTS}

\section{Course of natural succession}

Species richness, diversity (Shannon index) and evenness started to decline between the 10th and the 12 th weeks of undisturbed succession in 2000, when blue mussel abundances increased dramatically as a consequence of a massive spat fall (Fig. 2). Mussel abundance and diversity parameters were inversely correlated (species richness: $\operatorname{src} R=-0.63, \mathrm{p}<0.001$; Shannon index: $\operatorname{src} R=-0.73, \mathrm{p}<0.001$; evenness: $\operatorname{src} R=-0.65, \mathrm{p}<0.001)$.

\section{Procedural controls}

No significant differences in community composition or in diversity parameters between controls and procedural controls were found for any sampling date (Table 2). Thus, the mechanical process of breaking through the water surface can be ignored.

Table 2. Student's $t$-test and ANOSIM results of comparisons between controls and procedural controls during study on 3 mo old fouling communities in 2000. For $t$-test results, df $=10$ and $n=6$ in all cases

\begin{tabular}{|lll|}
\hline & $t$-test & ANOSIM \\
\hline 6th wk & $\begin{array}{l}\text { Species richness: } t=0.57, \mathrm{p}=0.58 \\
\text { Shannon index: } t=0.43, \mathrm{p}=0.68\end{array}$ & $\mathrm{R}=-0.03, \mathrm{p}=0.54$ \\
& Evenness: $t=-0.97, \mathrm{p}=0.92$ & \\
14th wk & $\begin{array}{l}\text { Species richness: } t=-0.28, \mathrm{p}=0.78 \\
\text { Shannon index: } t=-0.70, \mathrm{p}=0.5\end{array}$ & $\mathrm{R}=-0.04, \mathrm{p}=0.61$ \\
& Evenness: $t=-0.93, \mathrm{p}=0.37$ & \\
\hline
\end{tabular}




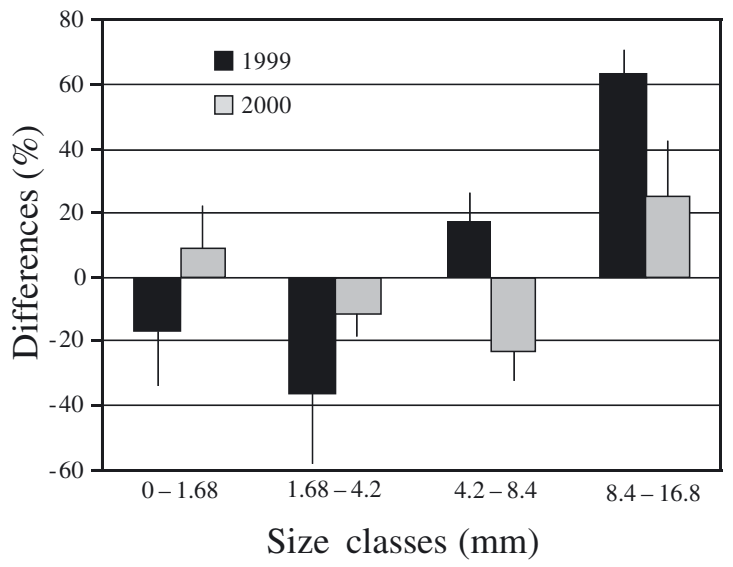

Fig. 3. Mytilus edulis. Relative increase/decrease (mean $\pm \mathrm{SE}$ ) in proportions of juveniles in 4 size classes between beginning of experiment and last sampling date (1999 and 2000 respectively). Size class ranges selected using ocular scale. Mussel abundance and size distribution of randomly chosen panels (examined at beginning of the study) were compared to undisturbed controls ( $\mathrm{n}=3$ in 1999, $\mathrm{n}=6$ in 2000)

\section{Climatic data and mussel growth rates}

The 2 consecutive study years differed markedly in regard to the weather conditions prevailing in September and October. Monthly mean water temperatures were significantly higher $\left(2.5^{\circ} \mathrm{C}\right.$ on average $)$ in September 1999 than in September of the following year (Kruskal-Wallis ANOVA: $H=32.65, \mathrm{p}<0.001$ ). The monthly mean air temperature in September 1999 was significantly higher than in September 2000 ( $t$-test: $\left.t_{58}=6.05, \mathrm{p}<0.001\right)$, with an average difference of $5.6^{\circ} \mathrm{C} ; 11^{\circ} \mathrm{C}$ was the largest difference between equivalent days. Mean solar radiation was significantly higher (monthly average difference of $87 \mathrm{~W} \mathrm{~m}^{-2}$ ) in October 1999 than in October 2000 (Kruskal-Wallis ANOVA: $H=5.97, \mathrm{p}<0.05)$. The monthly average rainfall did not differ significantly between years for either month.

Juvenile blue mussels exhibited higher growth rates during the experimental phase in 1999 (Fig. 3).

\section{Communities after 3 mo}

Year 1999

At the end of the undisturbed maturation period, communities were dominated by blue mussel spat (72\%; all percentage cover values are means of 4 panels) and by the barnacle Balanus improvisus (22\%). There were 5 other species present (the algae Enteromorpha sp. and Ceramium strictum and the invertebrates Polydora sp., Membranipora membranacea and Laomedea flexuosa), but their respective proportions did not exceed $5 \%$. The combined benthic diatoms covered $7 \%$ of the panel surface on average.

In the 4 th week, all diversity parameters showed a unimodal pattern (species richness: $\operatorname{pr} R^{2}=0.59, \mathrm{p}<$ 0.001; Shannon index: $\mathrm{pr} R^{2}=0.43, \mathrm{p}<0.001$; evenness $\left.\mathrm{pr} R^{2}=0.20, \mathrm{p}<0.01\right)$. After $8 \mathrm{wk}$ the unimodal diversity-disturbance relationship became less pronounced in the case of the Shannon index $\left(\mathrm{pr} R^{2}=0.16, \mathrm{p}<0.05\right)$ and evenness $\left(\mathrm{pr} R^{2}=0.19, \mathrm{p}<0.05\right)$ and was not significant for species richness.

After $12 \mathrm{wk}$, the majority of species had disappeared from the undisturbed controls, while mussels covered $100 \%$ of the panels. The few remaining species were epibiotic forms. Species numbers on control panels dropped from 5.5 on average at the beginning of the experiment to 2.5 after 3 mo. Species richness was highest at intermediate disturbance levels: panels exposed for $1.5 \mathrm{~h} \mathrm{~d}^{-1}$ bore 6 species on average, while controls and panels exposed for $6 \mathrm{~h} \mathrm{~d}^{-1}$ bore $<3$ species (Fig. 4). Shannon index and evenness showed the
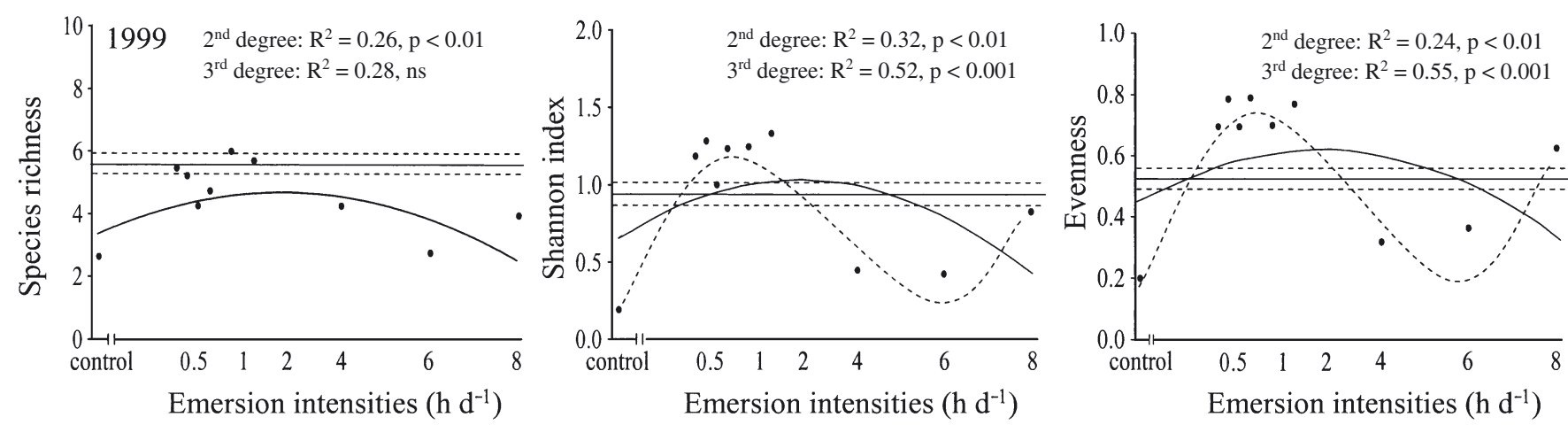

Fig. 4. Diversity parameters of 3 mo old communities in 1999 after 12 wk experiment duration. Data points: mean values for 4 settlement panels in each treatment; continuous horizontal line: initial value; dashed line: \pm SE; continuous regression curve: 2nd-degree polynomial function; dashed regression curve: 3rd-degree polynomial function. Regression lines shown only for significant relationships $(\mathrm{p}<0.05)$ 


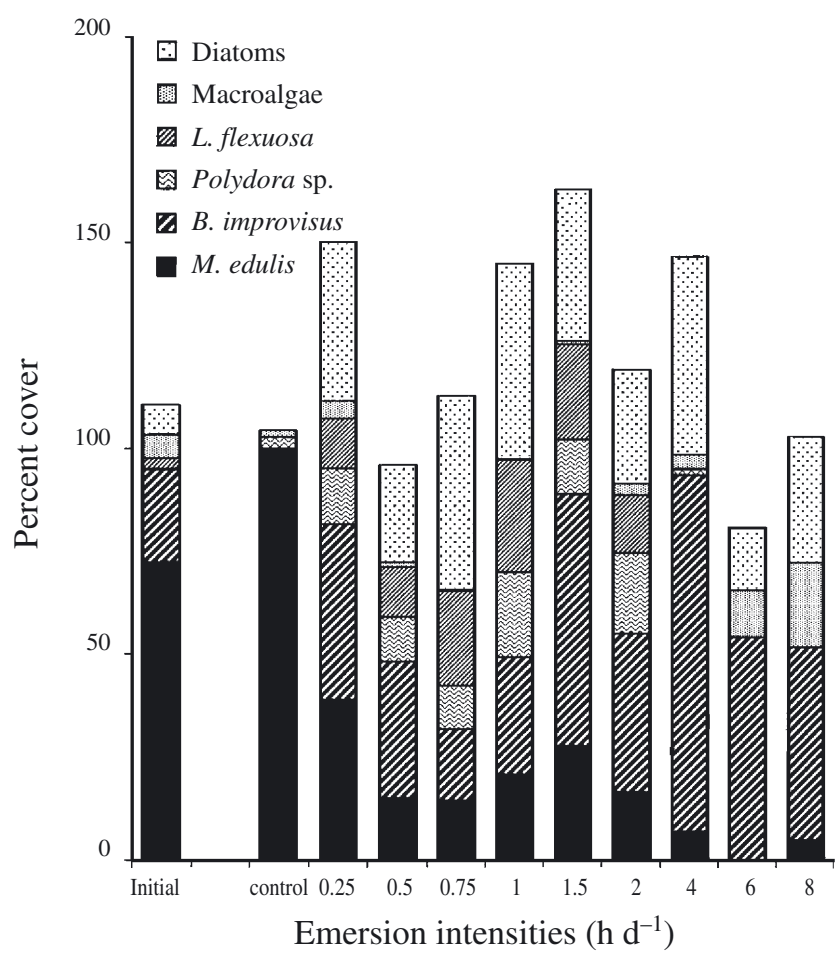

Fig. 5. Mean percent cover of predominant settlers (species accounting for $99 \%$ of total cover on average) in 3 mo old fouling communities after $12 \mathrm{wk}$ experiment duration across 10 intensity disturbance levels (including control) in 1999. Proportions in 3 mo old initial communities are shown in the left-hand column. L. flexuosa: Laomedea flexuosa; $B$. improvisus: Balanus improvisus; $M$. edulis: Mytilus edulis

same pattern. Second degree polynomial regression analysis revealed significant unimodal disturbancediversity relationships for all 3 parameters (species richness: $\operatorname{pr} R^{2}=0.26, \mathrm{p}<0.01$; Shannon index: $\operatorname{pr} R^{2}=$ 0.32, p < 0.01; evenness: $p r R^{2}=0.24, \mathrm{p}<0.01$; Fig. 4).

After $12 \mathrm{wk}$, blue mussel cover was reduced in all treated assemblages. On the least disturbed panels, Mytilus edulis cover was $40 \%$; this dropped to $<20 \%$ in the intermediate disturbance range and to $\leq 5 \%$ on panels exposed to air for $\geq 6 \mathrm{~h} \mathrm{~d}^{-1}$ (Fig. 5). Balanus improvisus dominated on panels exposed for 1.5, 4, 6 and $8 \mathrm{~h} \mathrm{~d}^{-1}$, apparently benefiting from the absence of blue mussels. Algae abundance increased at higher disturbance-intensity levels, while the invertebrates Laomedea flexuosa and Polydora sp. were more abundant on the panels exposed for shorter periods. The proportions of algae, including macroalgae and diatoms, significantly increased with increasing disturbance level $\left(\operatorname{lr} R^{2}=0.15, \mathrm{p}<0.05\right)$. Concurrently, all 3 diversity parameters were higher at the most extreme exposure levels, which resulted in a sinusoidal pattern of diversity over the entire disturbance gradient (3rddegree polynomial regression analysis: species richness $\operatorname{pr} R^{2}=0.28$, not significant; Shannon index: $\operatorname{pr} R^{2}=$ 0.52, p < 0.001; evenness: $p r R^{2}=0.55, \mathrm{p}<0.001$, Fig. 4).
After $28 \mathrm{wk}$ of the emersion treatment, the unimodal pattern was even more conspicuous. Diversity parameters were low in the controls and in the 6 and $8 \mathrm{~h}$ treatments, while they were elevated (sometimes above their initial value) in the low and intermediate treatments (2nd-degree polynomial regression analysis: species richness: $\operatorname{pr} R^{2}=0.59, \mathrm{p}<0.001$; Shannon index: $\operatorname{pr} R^{2}=0.53, \mathrm{p}<0.001$; evenness: $\operatorname{pr} R^{2}=0.20, \mathrm{p}<$ 0.05). Diatoms were highly abundant on all treated panels, while ephemeral macroalgae were absent at this season of the year.

Year 2000

After 3 mo maturation, blue mussels Mytilus edulis covered $84 \%$ of the panel surfaces on average, while Balanus improvisus contributed $16 \%$ (Fig. 6). The remaining community comprised 3 epibiotic algal species and the polychaete Polydora sp.

After $6 \mathrm{wk}$ of emersion treatment, species richness declined monotonically with increasing disturbance ( $\operatorname{lr} R^{2}=0.12, \mathrm{p}<0.001$ ), while the Shannon index- and evenness-disturbance relationships were not significant. After 14 wk of emersion treatment, the regression analysis revealed a significant U-shaped pattern across the 7 disturbance intensity levels for species richness

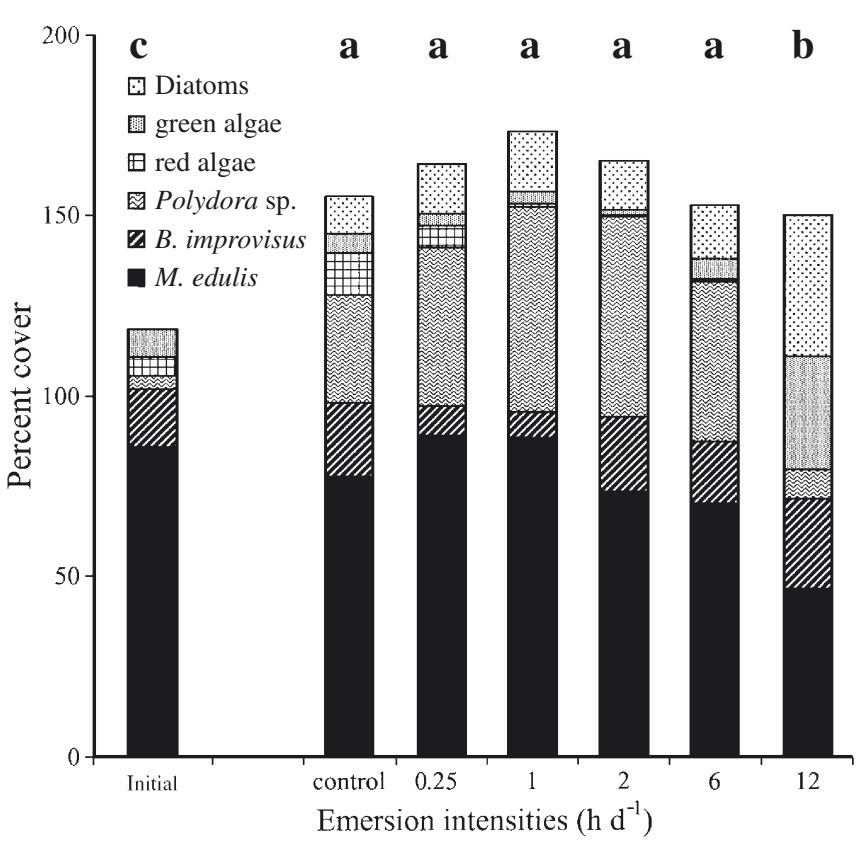

Fig. 6. Mean percentage cover of predominant settlers (species accounting for $98 \%$ of total cover on average) in 3 mo old communities after 14 wk experiment duration across 7 intensity disturbance levels in 2000. Proportions in 3 mo old initial communities are shown in the left-hand column. Different letters above bars indicate significant differences in community composition (ANOSIM; $\mathrm{p}<0.05$ ). Species abbreviations as in Fig. 5 

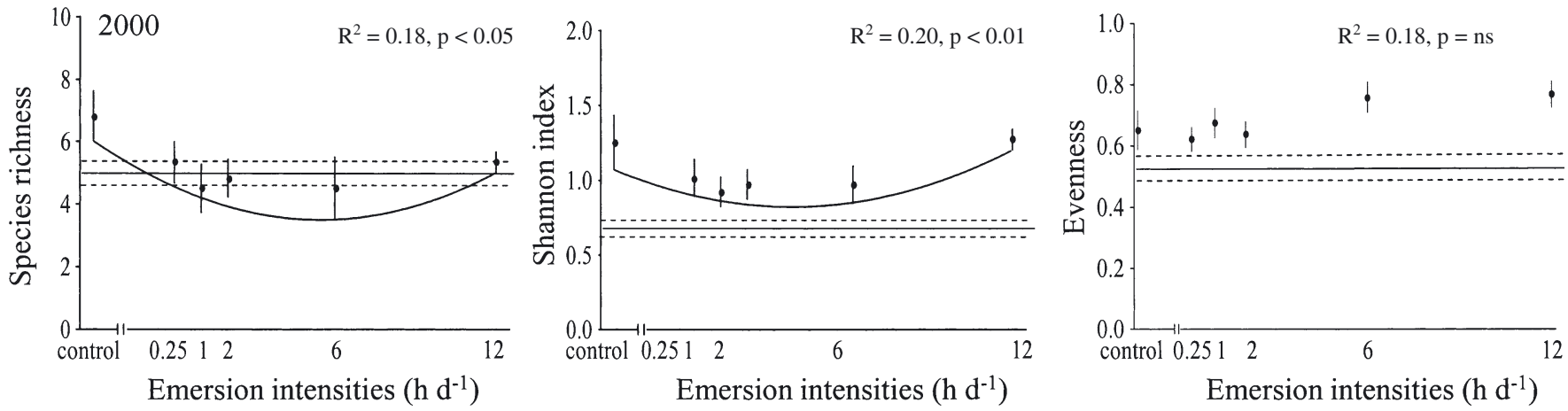

Fig. 7. Diversity parameters of 3 mo old fouling communities in 2000 after 14 wk experiment duration. Data points: mean $( \pm$ SE) values for replicate panels $(\mathrm{n}=6)$. Further details as for Fig. $4 . \mathrm{ns}=$ not significant

$\left(\operatorname{pr} R^{2}=0.18, \mathrm{p}<0.05\right)$ and the Shannon index $\left(\operatorname{pr} R^{2}=\right.$ $0.20, \mathrm{p}<0.05)$. The relationship between evenness and disturbance was non-significant (Fig. 7). During the entire study, mussel cover was not significantly affected by the emersion levels applied and did not fall below $70 \%$ on average, except at the $12 \mathrm{~h}$ exposure level, which depressed mussel cover below $50 \%$ on average (Fig. 6). Species richness and the Shannon index were inversely correlated with the presence of Mytilus edulis (species richness: $\operatorname{src} R=-0.42, \mathrm{p}<0.01$; Shannon index: $\operatorname{src} R=-0.79, \mathrm{p}<0.001)$. Macroalgae cover was positively correlated with disturbance intensity $\left(\operatorname{lr} R^{2}=0.18, \mathrm{p}<0.001\right)$. For these reasons, communities at the $12 \mathrm{~h}$ emersion level differed significantly from those in all other treatments (Table 3, Fig. 6).

\section{Communities after 12 mo}

After 1 yr of undisturbed succession, blue mussels dominated all panels, with 100\% cover (Fig. 8). There were 7 further species associated with Mytilus edulis: Ectocarpus sp., Ceramium strictum, the peritrich ciliate Vorticella sp., Laomedea flexuosa, Membranipora membranacea, Polydora sp. and Balanus improvisus.

U-shaped diversity-disturbance relationships emerged as early as 1 mo after initiation of the experiment. Regression analysis confirmed a significant relationship for the Shannon index $\left(\mathrm{pr} R^{2}=0.42, \mathrm{p}<0.05\right)$ and evenness $\left(\operatorname{pr} R^{2}=0.53, \mathrm{p}<0.001\right)$, while the disturbance-species richness relationship was not significant. The situation was the same after 8 wk (Shannon index: $\operatorname{pr} R^{2}=0.31, \mathrm{p}<0.01$, evenness: $\operatorname{pr} R^{2}=$ $0.26, \mathrm{p}<0.05)$. In the 12 th week, all diversity-disturbance relationships were signifi-
Table 3. Comparison of R- and p-values (pairwise comparisons: ANOSIM) between assemblages at $12 \mathrm{~h}$ exposure and initial level, $12 \mathrm{~h}$ exposure and control, and $12 \mathrm{~h}$ exposure and other exposure levels of $3 \mathrm{mo}$ old communities after $14 \mathrm{wk}$

\begin{tabular}{|rcc|}
\hline \multicolumn{1}{|c}{ Comparison } & $\mathrm{R}$ & $\mathrm{p}$ \\
\hline Initial $\times 12 \mathrm{~h}$ & 0.625 & $<0.01$ \\
Control $\times 12 \mathrm{~h}$ & 0.317 & $<0.05$ \\
$0.25 \mathrm{~h} \times 12 \mathrm{~h}$ & 0.487 & $<0.01$ \\
$1 \mathrm{~h} \times 12 \mathrm{~h}$ & 0.539 & $<0.01$ \\
$2 \mathrm{~h} \times 12 \mathrm{~h}$ & 0.439 & $<0.01$ \\
$6 \mathrm{~h} \times 12 \mathrm{~h}$ & 0.346 & $<0.01$ \\
\hline
\end{tabular}

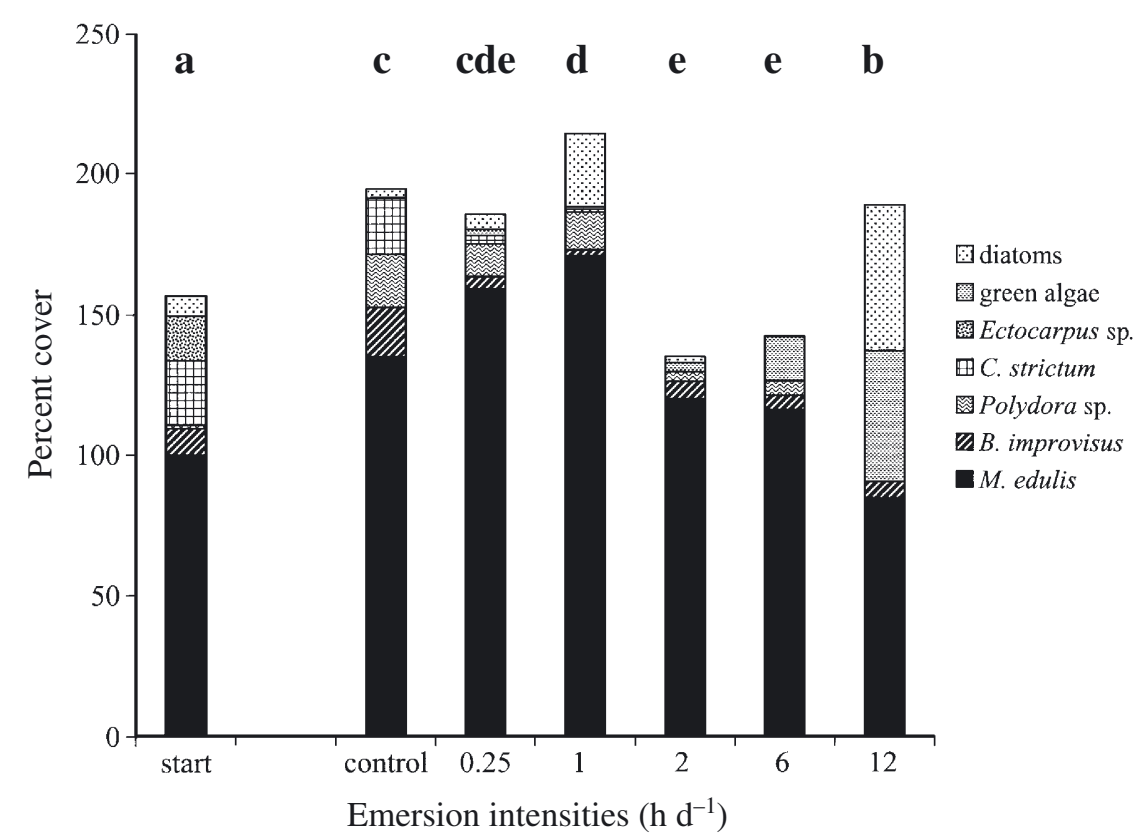

Fig. 8. Mean percentage cover of predominant settlers (species accounted for $94 \%$ of total cover on average) in 12 mo old communities after $12 \mathrm{wk}$ experiment duration across 7 intensity disturbance levels in 2000. Proportions in 12 mo old initial communities are shown in left-hand column. Different letters above bars indicate significant differences in community composition (ANOSIM; $\mathrm{p}<0.05)$. C. strictum $=$ Ceranium strictum. Other abbreviations as in Fig. 5 
Table 4. Comparison of R- and p-values (pairwise comparisons: ANOSIM) between assemblages of the $12 \mathrm{~h}$ exposure level and initial level, $12 \mathrm{~h}$ exposure and control, and $12 \mathrm{~h}$ exposure and other exposure levels of 12 mo old communities after $12 \mathrm{wk}$

\begin{tabular}{|rcc|}
\hline \multicolumn{1}{|c}{ Comparison } & $\mathrm{R}$ & $\mathrm{p}$ \\
\hline Initial $\times 12 \mathrm{~h}$ & 0.742 & $<0.01$ \\
Control $\times 12 \mathrm{~h}$ & 0.538 & $<0.05$ \\
$0.25 \mathrm{~h} \times 12 \mathrm{~h}$ & 0.510 & $<0.05$ \\
$1 \mathrm{~h} \times 12 \mathrm{~h}$ & 0.644 & $<0.01$ \\
$2 \mathrm{~h} \times 12 \mathrm{~h}$ & 0.396 & $<0.05$ \\
$6 \mathrm{~h} \times 12 \mathrm{~h}$ & 0.302 & $<0.05$ \\
\hline
\end{tabular}

cantly U-shaped (species richness: $p r R^{2}=0.48, \mathrm{p}<$ 0.001; Shannon index $\mathrm{pr} R^{2}=0.66, \mathrm{p}<0.001$; evenness: $\operatorname{pr} R^{2}=0.53, \mathrm{p}<0.001$; Fig. 9). On all but the $12 \mathrm{~h}$ treatment panels, blue mussels occurred in several layers due to newly settled spat and exceeded $100 \%$ of cover. Only the highest disturbance level significantly impaired the 1 yr old bivalves (1-way ANOVA: df effect $=5$, MS effect $=0.13$, df error $=$ 18, MS error $=0.029, F=4.66, p<0.01)$. Mussel cover was significantly lower on these panels than on those of the $0.5 \mathrm{~h}$ treatment (Tukey's HSD: $\mathrm{p}<0.05$ ) and $1 \mathrm{~h}$ level (Tukey's HSD: $\mathrm{p}<0.01$ ).

Communities that experienced the most severe treatment level differed significantly from all others (Table 4). Proportions of algae (macroalgae + diatoms) were positively correlated with disturbance intensity and were highest under the severest emersion conditions ( $\operatorname{src} R=0.43, \mathrm{p}<0.05$, Fig. 8).

\section{DISCUSSION}

\section{Diversity-disturbance relationships}

Blue mussels dominated all undisturbed communities in both study years and their abundances were usually inversely related to species richness, evenness and diversity (Shannon index). In 1999, blue mussel cover was suppressed by the emersion treatments, and the unimodal relationship between disturbance and diversity predicted by the IDH was recorded as a part of a more comprehensive sinusoidal pattern (Fig. 10A). In 2000, however, disturbance effects on mussel abundance were absent or small and the observed disturbance-diversity relationships were not significant or were U-shaped (Fig. 10B). In the following discussion we postulate that this observation does not contradict the IDH, and propose the sinusoidal pattern as an extension of the classical concept that encompasses all diversity-disturbance relationships observed in former IDH studies.

\section{Climatic modification of disturbance strength}

Between the 2 study years 3 factors differed markedly and presumably contributed to the contrasting patterns of the disturbance-diversity relationships.

(1) Abundance of recruits on undisturbed panels: In 2000 diversity in the undisturbed controls of the 3 moold communities increased slightly during the experiment through recruitment of further fouling species such as the athecate hydrozoan Clava multicornis, the thecate hydrozoan Laomedea flexuosa and the protozoan Vorticella sp. By contrast, no new recruitment occurred on the control panels in 1999. In combination with the exclusion by the dominant blue mussel of those species already present (see following paragraph), this led to a low diversity in the 1999 controls. No conclusive explanation was found for the absence of recruits in this year.

(2) Mussel growth rates: Competitive exclusion of nearly all other species by the blue mussel took place on the control panels in 1999. In 2000 the mussel was also dominant, but occupied $<100 \%$ of the control panel surfaces at the end of the study of 3 mo old communities. This restriction of dominance could have been caused by lower mussel growth rates in 2000, possibly due to lower water temperatures.

(3) Climatic modification of disturbance strength: Higher air temperatures and higher insolation in 1999 should have amplified the detrimental impact of a given emersion treatment by causing higher tissue temperatures, higher rates of tissue-water loss due to evaporation and more severe tissue damage due to UV radiation in organisms lacking morphological protection.

Therefore, in 1999, the dominant competitor, the blue mussel Mytilus edulis, was more heavily impacted by the experimental disturbances. Space for colonization was opened to various degrees on all treated panels. This led to increased diversity in the intermediate disturbance range, because species able to tolerate emersion conditions (e.g. the barnacle Balanus improvisus, polychaetes of the genus Polydora, the emersion-resistant hydrozoan Laomedea flexuosa and benthic diatoms) had the opportunity to settle or spread from their refuges. Under these circumstances, the net effect of intermediate disturbance on diversity was positive. In 2000, disturbance effects on blue mussels were absent, and subdominant species were not released from competition. The absence of a disturbance impact on the dominant competitor in 2000 was very likely attributable to colder and cloudier weather conditions in this year. Although overall disturbance strength was lower than in 1999, desiccation-sensitive species (e.g. the red algae Ceramium strictum and Polysiphonia elongata as well as the hydrozoan Clava multicornis) were impaired by intermediate and severe disturbances. This resulted in a stagnation 

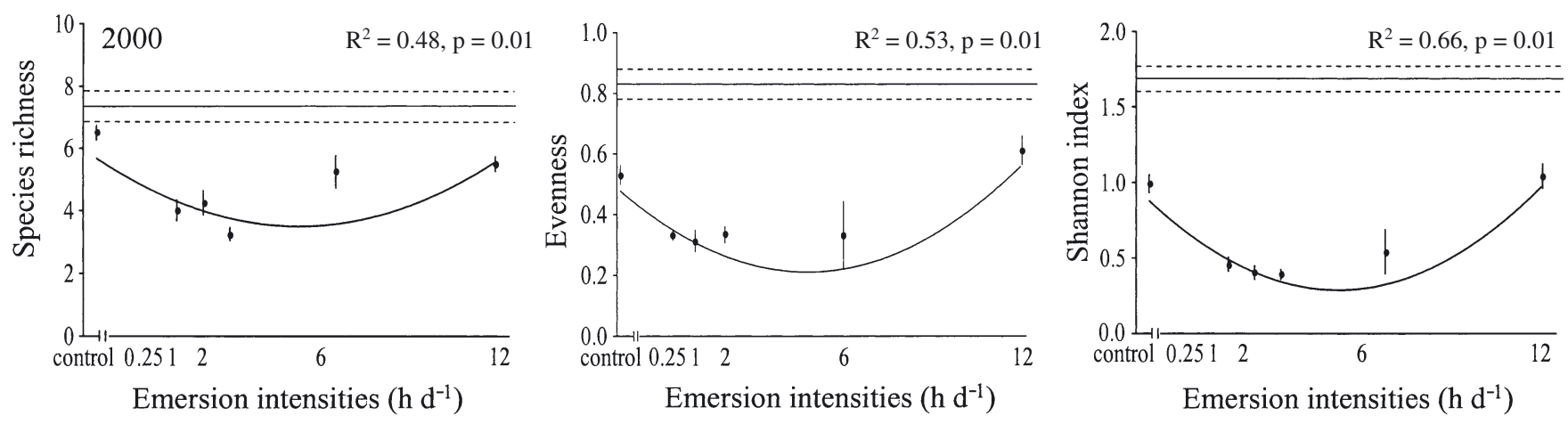

Fig. 9. Diversity parameters of 12 mo old fouling communities in 2000 after 12 wk experiment duration. Data points: mean $( \pm$ SE) values for replicate panels $(n=4)$. Further details as for Fig. 4

(in the 3 mo old communities) or even reduction (in the 12 mo old communities) of diversity in the intermediate disturbance range. In this case, the net effect of intermediate disturbance on diversity was negative. This observation underlines the fact that experimentally applied disturbances can be altered by environmental parameters, resulting in shifts of the actual disturbance regime. For this reason, in experimental studies on the IDH, the experimenter has to distinguish carefully between intended and actually realized disturbance regimes.

\section{Effects of emersion on species abundance}

For sessile marine invertebrates emersion is accompanied by restricted food supply and respiration (Widdows et al. 1979, Burnett et al. 1991, Sadok et al. 1999). Overheating induces the production of heat-stress proteins, a process that is associated with metabolic costs (Hofmann 1999). Desiccation, a consequence of prolonged emersion, means the loss of body water, dehydrated tissues and altered osmotic conditions of inner- and extracellular fluids. Osmotic stress adversely affects overall organism fitness, since all mechanisms used by marine invertebrates to overcome salinity fluctuations are associated with metabolic cost (Sadok et al. 1997). Because of its modification of DNA molecules and proteins ultraviolet-B radiation (UVBR) is a threat to all invertebrates that lack morphological protection. Oxidative stress, mediated by peroxides and free radicals, increases the need for anitoxidative substances, burdens the immune system and modifies cell membranes. Growth and fecundity are reduced and mortality is enhanced. Early life stages are more sensitive to UVBR due to their high developmental activity, their small size (optical radius), their low morphological complexity and their lack of protective structures (Adams \& Shick 1996, 2001).

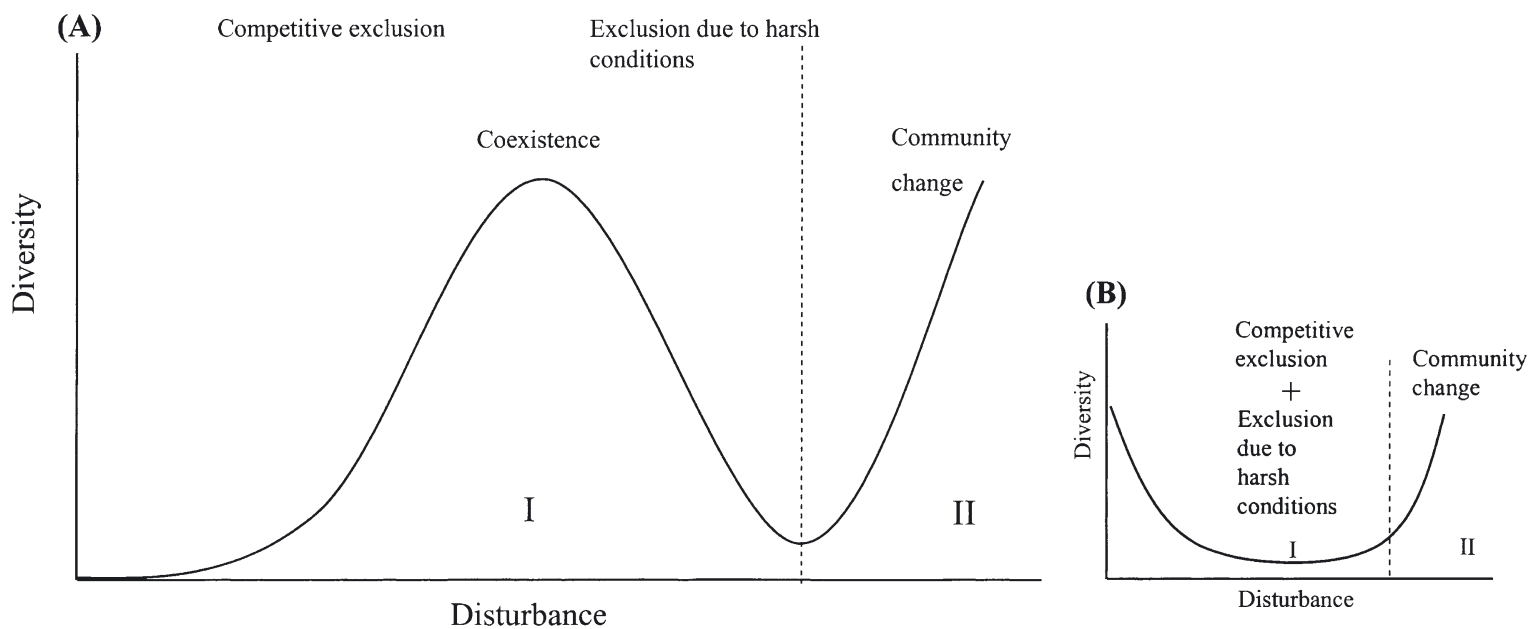

Fig. 10. (A) Sinusoidal disturbance-diversity relationship in 1999. (B) U-shaped curve emerged along the disturbance gradient in 2000. Difference in second year was due to absence of competitive exclusion in undisturbed controls, a negative net effect of intermediate disturbance, and extension of experimentally applied disturbance gradient. The latter modification compensated for lower overall disturbance strength in the second year and facilitated an increase in diversity at the extreme end of the disturbance gradient due to an incisive change in community composition. Roman numerals indicate different com-munity states 
In intertidal algae species, photosynthesis rates are generally restricted during emersion, and high insolation can even lead to a total cessation of photosynthesis due to photoinhibition and/or photodamage of Photosystem II (Davison \& Pearson 1996). Further adverse effects of emersion on macroalgae have been documented in numerous studies: algae experience nutrient shortage during periods of emersion (Schonbeck \& Norton 1979). Heat damage, e.g. the dehydration of proteins and disintegration of cell membranes, is a consequence of thallus overheating during periods of emersion (Bell 1995), while the concomitant dehydration of tissues interrupts photosynthesis and damages cell membranes (Schonbeck \& Norton 1980, Dudgeon et al. 1989). Reduced growth rates and enhanced mortality are a consequence of osmotic changes in thallus surfaces due to rainfall (Ohno \& Miyanoue 1980, Arasaki 1981, Wiencke \& Davenport 1987). In the absence of a protective water-column, algae experience enhanced rates of UVBR. This restricts productivity (Calkins \& Thordardottir 1980, Ekelund 1990, Häder et al. 1995), impairs gene expression (Mitchell \& Karentz 1993), disintegrates cell membranes (Häder \& Worrest 1991) and generates reactive species (Karentz \& Bosch 2001).

Thus, direct impact of emersion should generally be negative while indirect positive impact may occur when dominant competitors are more severely affected.

Direct and indirect effects of emersion disturbance on species abundance were observed for spionid polychaetes of the genus Polydora in the present study. These worms exhibited highest percent cover in the intermediate disturbance range in both study years. The genus Polydora comprises euryoecius species, which are protected against at least some of the detrimental effects of emersion by their tubes. The worms could have benefitted from decrease in blue mussel cover in 1999 and macroalgae cover in 2000 in the intermediate disturbance range. The decrease in mussel abundance opened up space for the recruitment of these tube-dwelling polychaetes. Simultaneously, predation pressure on worm larvae due to cumulative mussel filtration was reduced. The decrease in algae cover presumably enhanced the availability of food particles for the surface deposit-feeders in the second study year. Beyond a certain threshold in emersion intensity, however, the indirect beneficial effects of disturbance were counteracted by its direct detrimental effects: the polychaetes could not tolerate disturbance levels beyond $2 \mathrm{~h} \mathrm{~d}^{-1}$ in 1999 or $6 \mathrm{~h} \mathrm{~d}^{-1}$ in 2000 . The different threshold levels in the 2 years emphasize the climatic modification of disturbance strength.

A similar situation was observed for Laomedea flexuosa in 1999. The hydrozoan showed highest cover in the intermediate disturbance range $\left(0.25\right.$ to $\left.2 \mathrm{~h} \mathrm{~d}^{-1}\right)$, while it was absent from settlement panels above this disturbance level and in the controls. Presumably, $L$. flexuosa is protected against detrimental effects of emersion by its chitinous perisarc. Furthermore, it can retract its delicate hydranths into a hydrotheca. By this means the hydrozoan is able to tolerate environmental conditions at midshore level (its habitat in North Sea intertidal areas) (Hayward \& Ryland 1995). In 1999 it presumably benefitted from the space opened by the decrease in blue mussel and barnacle abundance under intermediate disturbance conditions.

Ambiguous effects of intermediate emersion treatments were observed for the barnacle Balanus improvisus in the 2 studies on 3 mo old communities. In 1999 the barnacle showed highest cover proportions under emersion conditions exceeding $1 \mathrm{~h} \mathrm{~d}^{-1}$. In 2000 the indirect beneficial effects of disturbance on barnacle abundances shifted to the most severe disturbance conditions. Only at this disturbance level were proportions of Mytilus edulis markedly reduced. Once again this response shift illustrates the influence of the climatic difference between the 2 years.

Negative effects of intermediate as well as severe disturbance levels were detected for the athecate hydrozoan Clava multicornis in the study on 3 mo old communities in 2000. The hydrozoan was absent from panels that experienced more than $1 \mathrm{~h}$ of emersion $\mathrm{d}^{-1}$. Due to the lack of a protective hydrotheca this species is presumably more susceptible to emersion than is Laomedea flexuosa. Consistent with this, in intertidal areas, it inhabits habitats below midshore level (Hayward \& Ryland 1995).

The red algae Ceramium strictum and Polysiphonia elongata were adversely affected by intermediate and severe disturbance conditions. In the North Sea, both species are restricted to the lower intertidal or the subtidal (Kornmann \& Sahling 1983). Therefore, they presumably lack adaptations to prolonged exposure to the air.

In both studies on 3 mo old communities, benthic diatoms had highest proportional cover in the intermediate disturbance range. These unicellular algae are protected against adverse effects of emersion by their cell walls and by the formation of dense biofilms that retain water and buffer environmental stress. This protective mechanism seems to be very efficient, since in all 3 studies diatoms were abundant even under the most severe disturbance conditions. Diatoms are abundant and highly productive in intertidal mud flats (McIntire \& Moore 1977); possibly they profit from enhanced light regimes or elevated $\mathrm{CO}_{2}$ availability during periods of emersion.

Green algae such as Enteromorpha sp., Ulvopsis grevillei and Chaetomorpha tortuosa benefitted from severe disturbance conditions. These algae species 
inhabit the intertidal up to its upper limits (Kornmann \& Sahling 1983), where they are released from competition by red and brown algae. For this reason they are presumably well adapted to emersion conditions. In general, we found red algae (Ceramium strictum and Polysiphonia elongata) in the controls and under weak disturbance regimes, while green algae (C. tortuosa, Enteromorpha sp. and U. grevillei) were abundant under the most severe disturbance conditions. This confirms the assumption that community composition along the applied disturbance gradient at least partially mirrors the vertical zonation of organisms in North Sea intertidal areas.

\section{Disturbance-induced community change}

In contrast to the predictions of the IDH, we found that diversity increased under the most severe disturbance conditions in the majority of cases in all 3 experiments. It initially decreased toward the extreme end of the gradient due to harsher conditions, but increased again when an alternative community state, comprised mainly of green algae and diatoms, was established on the most severely disturbed panels. This was also the case in 2000, although overall disturbance strength was lower due to climatic modification. Presumably no such effect would have been observed had not the disturbance gradient been extended at its harshest extremity. This compensated for lower disturbance strength, and as a consequence of this, fouling communities switched from mussel to algae dominance under the most severe disturbance conditions in 2000 .

The observation of diversity recovery under extreme disturbance conditions is new in the IDH-related discussion, and suggests an extension of the classical unimodal pattern (Fig. 10A). Additionally it implies a connection between the IDH and the multiple stable-state hypothesis (Sutherland 1974, Gray 1977, May 1977). The latter hypothesis assumes that communities can exist in alternative stable states, while shifts between these are triggered by exogenous, stochastic events (Scheffer et al. 2001). Apparently, communities of ephemeral algae represent an alternative state of (usually mussel-dominated) fouling communities in the system investigated. No such alternative equilibria for Western Baltic hard-bottom communities have yet been described, but Dürr \& Wahl (in press), who simulated specific predation on blue mussels during the succession of hard-bottom communities in this system, observed communities to be dominated by the barnacle Balanus improvisus, the spionid Polydora sp. and the crustacean Corophium volutator when Mytilus edulis was removed. The fact that Dürr \& Wahl (in press) disturbed the communities in a species-selective way restricts a comparison between their study and ours. Furthermore, we did not test whether algae communities are stable in the absence of a disturbance impact, an attribute required by the multiple stablestate hypothesis. Nevertheless, a search for alternative community equilibria in future experimental disturbance-diversity studies will be rewarding, since it could give rise to the mergence of 2 important ecological concepts.

\section{Sinusoidal model-extension of the classical concept}

Our observations also raise the question as to whether the predictions of the IDH are only valid within 1 focussed community state. Such limitation, however, might increase the danger of tautology, since unimodal relationships are more easily encountered when alternative community states are ignored.

The multitude of disturbance-diversity relationships found in former experimental and/or observational studies on the IDH (Mackey \& Currie 2001) is difficult to reconcile with the classical concept. We conclude, with respect to our observation of a sinusoidal disturbance-diversity relationship in the first study year (Fig. 10A), that findings of disturbance-diversity patterns other than the unimodal curve (as was the case in the second year of our study) do not necessarily question the IDH in general. Disturbance ranges realized or observed in studies which have reported monotonically increasing, monotonically decreasing or U-shaped disturbance-diversity relationships could have generated different sections of the sinusoidal curve in Fig. 10A. In such cases, the entire pattern was presumably not observed because of too narrowly chosen disturbance gradients, the absence of competitive exclusion, or environmental modification of disturbance strength.

\section{Testing IDH in the field}

A wide disturbance range seems to be essential for a valid experimental test of the IDH and, as shown in this study, environmental factors that could modify the impact of a disturbance must be considered. A number of experimental studies on the concept that have been conducted in marine benthic systems, and which yielded ambiguous results, support our view on experimental field tests of the IDH. Some of the contradictory findings have been explained by the presence or absence of a dominant competitor: Carpenter (1981) and Sammarco (1982) worked on the effects of different grazing intensities of the sea urchin Diadema antil- 
larum on reef algae communities; Carpenter (1981) found a maximum of algal species richness at intermediate D. antillarum densities, while Sammarco (1982) conducted an experiment at the same study site and detected a monotonous decline of species richness with increasing number of urchins. Unexpectedly, very similar experiments yielded an ambiguous picture and Sammarco (1982) argued that in his study the unimodal pattern did not emerge because dominant algae were absent. This corresponds to our observations concerning the absence of competitive exclusion in our second study year. Hixon \& Brostoff (1983) generated 3 different intensity levels of fishes grazing on reef algae and found highest algae species richness at the intermediate level. They observed that dominant algae were present and were effectively harmed by this disturbance. This is consistent with our observation that impairment of the dominant competitor is essential for the occurence of a unimodal pattern.

\section{Community stability versus complexity}

With regard to disturbance susceptibility as a function of community age and complexity, we found that under similar disturbance regimes, the initially more diverse 1 yr old assemblages experienced a greater decline in diversity in the intermediate disturbance range than younger communities. This corresponds to the assumption that community stability decreases when complexity increases (Begon et al. 1996, PerezEspana \& Arrequin-Sanchez 2001).

This decline in diversity in the older communities was due to the suppression of associated species that had become established within the blue mussel matrix during the long undisturbed maturation period. Presumably, desiccation-sensitive forms such as the red alga Ceramium strictum, the brown seaweed Pilayella littoralis and the delicate protozoan Zoothamnion sp. suffered from the negative effects of emersion, while growth of the emersion-resistant species such as green algae of the genus Enteromorpha and the hydrozoan Laomedea flexuosa was hindered by the cumulative negative effects of competition by the dominant blue mussel and emersion conditions.

\section{CONCLUSIONS}

Our results highlight some of the problems associated with a valid test of the IDH and emphasize the importance of replicating experiments temporally in order to assess the influence of fluctuating environmental factors on the effects of a disturbance. We have extended the classical model to integrate a diversity- enhancing, disturbance-induced community change at the harsh end of a disturbance gradient. Additionally, on the basis of our observations, we suggest a possible conceptual linkage between the IDH and the multiple stable-state theory. Finally, we found community stability to be negatively correlated with community complexity.

Acknowledgements. We are grateful to the Wasser- und Schifffahrtsamt Lübeck, who kindly provided access to the study site and provided the rafts, and to the staff of the locks of KielHoltenau who were always generous with technical help. The authors wish to thank the staff of the Biozentrum's workshops for their indispensable help in designing, building and maintaining the experimental set-up. Critical reviews by R. Karez and S. Moorthi and 4 anonymous referees have improved the quality of this manuscript. This study was funded by the Deutsche Forschungsgemeinschaft (WA 708 6-1 + 6-2).

\section{LITERATURE CITED}

Adams NL, Shick JM (1996) Mycosporine-like amino acids provide protection against ultraviolet radiation in eggs of the green sea urchin Strongylocentrotus droebachiensis. Photochem Photobiol 64:149-158

Adams NL, Shick JM (2001) Mycosporine-like amino acids prevent UVB-induced abnormalities during early development of the green sea urchin Strongylocentrotus droebachiensis. Mar Biol 138:267-280

Arasaki S (1981) A comparison of the phenology of intertidal Porphyra on the coasts of Japan and western North America. Proc Int Seaweed Symp 8:273-277

Begon M, Harper JL, Townsend CR (1996) Ecology: individuals, populations and communities, 2nd edn. Blackwell Science, Oxford

Bell EC (1995) Environmental and morphological influences on thallus temperature and desiccation of the intertidal alga Mastocarpus papillatus Krützing. J Exp Mar Biol Ecol 191:29-55

Burnett LE, Jorgensen DD, Carol AK, Scholnick D (1991) Physiological responses of the barnacle Balanus nubilis to air exposure. Am Zool 31:68A

Calkins J, Thordardottir T (1980) The ecological significance of solar UV radiation on aquatic organisms. Nature 283: 563-566

Carpenter RC (1981) Grazing by Diadema antillarum (Philippi) and its effects on the benthic algal community. Mar Res 39:749-765

Clarke KR (1993) Non-parametric multivariate analyses of changes in community structure. Aust J Ecol 18:117-143

Connell JH (1978) Diversity in tropical rain forests and coral reefs. Science 199:1302-1309

Davison IR, Pearson GA (1996) Stress tolerance in intertidal seaweeds. J Phycol 32:197-211

Dudgeon SR, Davison IR, Vadas RL (1989) Effect of freezing on photosynthesis of intertidal algae: relative tolerance of Chondrus crispus and Mastocarpus stellatus. Mar Biol 101:107-114

Dürr S, Wahl M (in press) Competition, species exclusion, simulated specific predation, and diversity in a fouling community. J Ex Mar Biol Ecol

Ekelund NGA (1990) Effects of UV-B radiation on growth and motility of four phytoplankton species. Physiol Plant 78: 590-594 
Flöder S, Sommer U (1999) Diversity in planktonic communities: an experimental test of the intermediate disturbance hypothesis. Limnol Oceanogr 44:1114-1119

Gray JS (1977) The stability of benthic ecosystems. Helgoländer Wiss Meeresunters 30:427-444

Grime JP (1973) Competitive exclusion in herbaceous vegetation. Nature 242:344-347

Häder DP, Worrest RC (1991) Effects of enhanced solar ultraviolet radiation on aquatic ecosystems. Photochem Photobiol 53:717-725

Häder DP, Worrest RC, Kumar HD, Smith RC (1995) Effects of increased solar ultraviolet radiation on aquatic ecosystems. Ambio 24:174-180

Hayward PJ, Ryland JS (1995) Handbook of the marine fauna of north-west Europe. Oxford University Press, Oxford

Hixon MA, Brostoff WN (1983) Damselfish as keystone species in reverse: intermediate disturbance and diversity of reef algae. Science 220:511-513

Hofmann GE (1999) Ecologically relevant variation in induction and function of heat shock proteins in marine organisms. Am Zool 39:889-900

Huston MA (1979) A general hypothesis of species diversity. Am Nat 113:81-101

Karentz D, Bosch J (2001) Influence of ozone-related increases in ultraviolet radiation on Antarctic marine organisms. Am Zool 41:3-16

Kornmann P, Sahling PH (1983) Meeresalgen von Helgoland. Biologische Anstalt Helgoland, Hamburg

Lass HU, Magaard L (1995) Wasserstandsschwankungen und Seegang. In: Rheinheimer G (ed) Meereskunde der Ostsee. Springer-Verlag, Berlin, p 68-74

Mackey RL, Currie DJ (2001) The diversity-disturbance relationship: is it generally strong and peaked? Ecology 82: 3479-3492

May RM (1977) Thresholds and breakpoints in ecosystems with a multiplicity of stable states. Nature 269:471-477

McIntire CD, Moore WW (1977) Marine littoral diatoms: ecological considerations. In: Werner D (ed) The biology of diatoms. Blackwell, Oxford, p 333-371

Mitchell DL, Karentz D (1993) The induction and repair of DNA photodamage in the environment. In: Young AR, Björn LO, Moan J, Nultsch W (eds) Environmental UV photobiology. Plenum Press, New York, p 345-377

Ohno M, Miyanoue K (1980) The ecology of the food alga Enteromorpha prolifera. Rep Usa Mar Biol Inst Kochi Univ 2:11-17

Editorial responsibility: Otto Kinne (Editor), Oldendorf/Luhe, Germany
Perez-Espana H, Arrequin-Sancez F (2001) An inverse relationship between stability and maturity in models of aquatic ecosystems. Ecol Model 145:189-196

Petraitis PS, Latham RE, Niesenbaum RA (1989) The maintenance of species diversity by disturbance. Q Rev Biol 64: 393-418

Pickett STA, White PS (eds) (1985) The ecology of natural disturbance and patch dynamics. Academic Press, Orlando, FL

Sadok S, Uglow RF, Haswell SJ (1997) Haemolymph and mantle fluid ammonia and ninhydrin positive substances variations in salinity-challenged mussels (Mytilus edulis L.). J Exp Mar Biol Ecol 211:195-212

Sadok S, Uglow RF, Haswell SJ (1999) Some aspects of nitrogen metabolism in Mytilus edulis: effects of aerial exposure. Mar Biol 135:297-305

Sammarco PW (1982) Effects of grazing by Diadema antillarum Philipi (Echinodermata: Echinoidea) on algal diversity and community structure. J Exp Mar Biol Ecol 65: 83-105

Scheffer M, Carpenter S, Foley JA, Folke C, Walker B (2001) Catastrophic shifts in ecosystems. Nature 413:591-596

Schonbeck MW, Norton TA (1979) The effects of brief periodic submergence on intertidal fucoid algae. Estuar Coast Mar Sci 8:205-211

Schonbeck MW, Norton TA (1980) Effects on intertidal fucoid algae of exposure to air under various conditions. Bot Mar 23:141-147

Sutherland JP (1974) Multiple stable points in natural communities. Am Nat 108:859-873

Widdicombe S, Austen MC (1998) Experimental evidence for the role of Brissopsis lyrifera (Forbes, 1841) as a critical species in the maintenance of benthic diversity and the modification of sediment chemistry. J Exp Mar Biol Ecol 228:214-255

Widdicombe S, Austen MC (1999) Mesocosm investigation into the effects of bioturbation on the diversity and structure of a subtidal macrobenthic community. Mar Ecol Prog Ser 189:181-193

Widdows J, Bayne BL, Livingstone DR, Newell RIE, Donkin P (1979) Physiological and biochemical responses of bivalve molluscs to exposure to air. Comp Biochem Physiol 62: 301-308

Wiencke C, Davenport J (1987) Respiration and photosynthesis in the intertidal alga Cladophora rupestris (L.) Kuetz. under fluctuating salinity regimes. J Exp Mar Biol Ecol 114:183-197

Submitted: February 24, 2003; Accepted: May 18, 2004 Proofs received from author(s): August 12, 2004 